\title{
An Empirical Study on the Pedagogy of Multiliteracies of Business English Course
}

\author{
Xiao-si SONG ${ }^{1, a,{ }^{*}}$ \\ ${ }^{1}$ Harbin University of Commerce, Harbin, China, 150028 \\ a12627058@qq.com
}

Keywords: Pedagogy of Multiliteracies, Business English Course, Multi-modal

\begin{abstract}
Multiliteracies was coined in response to two significant changes in globalized environments: the proliferation of diverse modes of communication through new communications technologies such as the internet, multimedia, and digital media, and the existence of growing linguistic and cultural diversity due to increased transnational migration[1]. The main purpose of traditional English language pedagogy focuses on teaching and learning languages. So it is necessary to change the traditional teaching way in business English curriculum and emphasize students' multiliteracies ability to adapt the changing business world. This empirical research on the "Pedagogy of Multiliteracies of Business English Course" is conducted in foreign language department of Harbin University of Commerce. It shows that the Pedagogy of Multiliteracies has a positive influence in business English language acquisition and cross-cultural learning.
\end{abstract}

\section{Introduction}

As the continuing growth of global information technology, multi-modal has been deep into our lives. The way in which human beings learn about new things has been quietly changing. And the introduction of multi-media facilities and network teaching platform also makes the teaching module to show multi-modal. Multiliteracies is a new concept proposed by the New London Group (The New London Group, 1996), who then put forward the Multiliteracies Teaching Method. So how to train students' Multiliteracies becomes a new task of teaching based on multi-modal construction which becomes the main expression of cognition

\section{Literature Review}

\section{Multiliteracies}

Multiliteracies are a term coined in the mid-1990s by the New London Group [2]. Multiliteracies were first put forward by the New London Group in 1996 and are an approach to literacy theory and pedagogy. This approach highlights two key aspects of literacy: linguistic diversity, and multimodal forms of linguistic expression and representation. Its concept is to use a variety of forms in the rapid development of changing society, which is a rich, dynamic, non-materialized form [1]. Multiliteracies emphasizes that learners, based on past knowledge and experience, should read and figure out different modes of information, critically select and use multi-mode and a variety of information resources to effectively solve the problem. Its aim is to help students to adapt to economic globalization and change in language and cultural diversity in the times of rapid development of science and technology 


\section{Pedagogy of Multiliteracies}

Based on the idea of New London Group about how to carry out the Multiliteracies teaching, the Multiliteracies pedagogical approach involves four key aspects: Situated Practice, Critical Framing, Overt Instruction, and Transformed Practice. Situated Practice involves learning that is grounded in students' own life experiences. Critical Framing supports students in questioning common sense assumptions found within discourses. Overt Instruction is the direct teaching of "metalanguages" in order to help learners understand the components of expressive forms or grammars. Transformed Practice is where learners engage in situated practices based in new understandings of literacy practices [3].

As a kind of teaching theory, the Pedagogy of Multiliteracies is a new perspective of foreign language teaching reform practice. It overcomes the shortcomings of traditional language-centered indoctrination teaching mode and advocates the acquisition through visual, hearing, gesture, space and other channels Knowledge [4]. It suggests using network, picture, voice and other symbolic resources to learn language and culture, with a view to train learners to creatively use information and communication technology, to critically read and explain through the multi-mode of language, visual, auditory and to understand multimedia providing information. Therefore this kind of ability will lay a good foundation for improving the ability of language learning and intercultural communication [5].

\section{An Experimental Study on Pedagogy of Multiliteracies}

\section{Research Question}

The questions of this research include: Is there any difference between traditional teaching module and Multiliteracies teaching module? Dose the Pedagogy of Multiliteracies have positive influence on the students' ability to self-language learning and intercultural communication? Does the teaching module provide meaningful environment for their input and output of knowledge?

\section{Experiment Object and Proposal}

Experiments were carried out to validate the model. In this study, the authors point out that by contrasting the experiments, the Pedagogy of Multiliteracies is used in the experimental class and regular teaching method in the reference class. This study employs a comprehensive research method, through teaching practice and experiment, to gain data and analyzes and argue the results. This study sets up Class 1 of 2014 Business English Major of Harbin University of Commerce as the experimental class and Class 2 as the reference class. The experimental course is Business English Course, in which the multi -modal teaching module and the traditional teaching module are applied respectively, so as to carry on the teaching experimental research comparison.

\section{Experiment Tools}

There are three kinds of research tools used in the experiment. One is the questionnaires, classroom investigation questionnaire of the Multiliteracies teaching module, the second tool is the business oral test and the third one is the student's subjective evaluation, including the study diary or the weekly record, the interview and the feedback of execution of learner self-study plan. 
As for the first tool, scoring system is used for strategy learning (exercise and practice) of intercultural communication. The data will be processed using SPSS 13.0 statistical package. Pedagogy of Multiliteracies classroom questionnaire will be divided into three levels to do subjective evaluation.

Secondly, as for the business English oral test, there are two sets of questions, respectively, as the previous and afterwards questions. Each set has three types of questions including 40 topics. All the topics are handed out for the students to prepare two weeks earlier in advance and the final test subject is be decided by lot. Oral English part, the main test for students is to figure out their fluency usage of business terms, the relevance of the content, the normative degree of pronunciation, the correct degree of grammar and the degree of protocol of cross-cultural terms.

\section{Experimental Process}

This study is carried out in the Business English Course from the autumn term of 2014 to the spring term of 2015, which lasts 30 weeks. At the beginning of the term, the frequency of business oral English learning strategies used in the experimental class and reference class is tested and the needs of Business English Course learning are analyzed and investigated.

\section{The Teaching Process of Experimental Class}

Based on the analysis of learners' characteristics and the teaching objectives, this study proposes to design student-centered learning tasks. The students were instructed to use the role modeling language to construct the learning behavior model to realize the situated practice. The students offered the critical designed plan and proposed the learning task and strategy.

The construction of teaching mode is carried out from two aspects, situational presupposition and teaching construction. The situational presupposition presupposes the learning task of the business language to the real business English listening and speaking in different scenes, so that the students can transform the book knowledge into practical operation ability. And the teaching construction provides students with teaching resources and guidance and some practical solutions to the problem.

Based on the analysis of the learning characteristics of the integrated business English curriculum, the whole cycle construction program is guided by the teaching objectives, and combined with other business teaching materials such as "Experiential Business English Course" and the auxiliary teaching system, which implements teaching practice on the experimental class based on self-learning and multi-dimensional interactive learning, designs and puts forward learning tasks. During the implementation of the task, from the situated presupposition and teaching strategies, Microsoft Office PowerPoint is used to explain the demonstration and Microsoft software, other software is used to collect information integrated teaching content, Class network self-learning platform and other Internet terminals, such as mobile phones, PC, IPAD and other auxiliary teaching are also used to complete e-learning and mobile learning. All these above ultimately form the business English Multiliteracies teaching model. 


\section{The Teaching Process of Reference Class}

In the reference class is taught mainly in the traditional teaching module, multi-dimensional interaction not included. In the class, some business knowledge and language are taught, followed by analysis of business materials and finally student's language are evaluated by oral recitation.

At last at the end of each term, this study conducts a survey about intercultural communication and pragmatic application and a test of business English speaking ability between the experimental class and reference class.

\section{Results}

Questionnaire Statistics of Pedagogy of Multiliteracies Questionnaire of Classroom Survey are shown in Table 1.

Table 1. Results of Questionnaire Survey

\begin{tabular}{|l|l|l|l|}
\hline Serial Number & Option A & Option B & Option C \\
\hline 1 & $7.7 \%$ & $88.3 \%$ & $4 \%$ \\
\hline 2 & $20 \%$ & $80 \%$ & \\
\hline 3 & $31 \%$ & $69 \%$ & \\
\hline 4 & $11 \%$ & $89 \%$ & \\
\hline 5 & $13.5 \%$ & $86.5 \%$ & \\
\hline 6 & $1.8 \%$ & $91.8 \%$ & $6.4 \%$ \\
\hline 7 & $4.9 \%$ & $95.1 \%$ & \\
\hline 8 & $5.3 \%$ & $94.7 \%$ & \\
\hline 9 & $24 \%$ & $76 \%$ & \\
\hline 10 & $2.9 \%$ & $97.1 \%$ & \\
\hline 11 & $16 \%$ & $84 \%$ & \\
\hline 12 & $43 \%$ & $57 \%$ & \\
\hline 13 & $33 \%$ & $67 \%$ & \\
\hline 14 & $42 \%$ & $53 \%$ & $5 \%$ \\
\hline 15 & $12.6 \%$ & $87.4 \%$ & \\
\hline
\end{tabular}

Results of Business English Speaking Test Before and after the experiment, this study conducts two oral tests (pre-test and post-test) for the reference class and the experimental class. The results are shown in Table 2.

Table 2. Reference Class and Experimental Class Oral Test Results

\begin{tabular}{|l|l|l|l|l|l|l|}
\hline & & Mean & Covariance & Degree of Freedom & $\begin{array}{l}\text { Value of } \\
\mathrm{T}\end{array}$ & Probability \\
\hline $\begin{array}{l}\text { Pre } \\
\text { Test }\end{array}$ & $\begin{array}{l}\text { Reference } \\
\text { Class }\end{array}$ & 0.46 & 0.37 & 71 & 1.097 & 0.113 \\
\hline & $\begin{array}{l}\text { Experimental } \\
\text { Class }\end{array}$ & 0.38 & 0.45 & & & \\
\hline $\begin{array}{l}\text { Post } \\
\text { Test }\end{array}$ & $\begin{array}{l}\text { Reference } \\
\text { Class }\end{array}$ & 1.12 & 0.32 & 74 & 1.752 & 0.069 \\
\hline & $\begin{array}{l}\text { Experimental } \\
\text { Class }\end{array}$ & 1.09 & 0.36 & & & \\
\hline
\end{tabular}

As can be seen fromTable 2, before 30 weeks, the strategy employed means are respectively 0.46 for reference class and 0.38 for experimental class. Detected by $\mathrm{P}$ value, the probability is greater than 0.01 . This shows that the frequency of the two classes of strategies is lower and the usage of spoken language strategy is basically no difference between the two classes. So the relevance situation of strategy used is less. 
After 30 weeks of training, the mean of both reference class and the experimental class has increased, and the reference class average price is slightly higher than the experimental class. Tested by the 689P value, the probability is 0.069 , greater than 0.05 , less than 0.1, which shows that strategy usage has improved and there are differences.

\section{Analysis}

Through the questionnaire survey, oral test and student interviews, the results are showed as follows:

A New Self-Teaching Module. Multiliteracy teaching module can cultivate students' self-learning ability and help to construct new knowledge system. Such learning view and learning method can help students develop critical reading ability. It fully reflects the student learning initiative and builds their knowledge system. In the multimedia-assisted teaching process, the teacher is not only the organizer of the students' learning process but also a manager of their learning activities.

Benefiting both business English language equsition and crosscultural communication.Pedagogy of Multiliteracies makes the teaching process more vivid and the boring language learning more abundant. Meanwhile, the more abundant learning resources provided for the students can make the teaching content more malleable. So the formation of students' intercultural thinking and strategy has more meaningful influence, which will increase the students' input and output opportunities and improve the ability of intercultural communication.

\section{Conclusion}

This study demonstrates the feasibility and application value of theory of the Pedagogy of Multiliteracies in comprehensive business English teaching. In teaching practice, according to the specific teaching situation, the advantages of this teaching module should be fully played in scientific way.

\section{Acknowledgement}

This research was financially supported by Philosophy and Social Sciences Research Program of Heilongjiang Province: Research on the Model of the Feature of Business English "Triadic Reciprocal" Discipline (Grant No.: 16YYD11) and A Study on Ecological Module of Business English Talents Developing in Heilongjiang Province (Grant No.: 15EDB01)

\section{References}

[1] Cope, B. \& Kalantzis, M. (Eds.) Multiliteracies: Literacy Learning and the Design of Social Futures, Routlege: London, 2000.

[2] The New London Group. A pedagogy of Multiliteracies: Designing social futures. Harvard educational review, 1996, pp. 66 (1), 60-93.

[3] Cope, B., \& Kalantzis, M. (2015). The things you do to know: An introduction to the pedagogy of multiliteracies. In B. Cope \& M. Kalantzis (Eds.), A pedagogy of multiliteracies: Learning by design (pp. 1-36). London: Palgrave

[4] Xiaosi Song, An Experimental Study of International Business Negotiation Teaching Module Based on the Information Technology, J. Learning Theory,1 (2014) 
[5] Yun Cao, A Study of Multi-reading Ability in Multiliteracies Education, J. Foreign Language Learning Journal, 4(2015). 